\title{
INDEFINITE BOUNDARIES LED TO DISPUTES
}

\author{
By RONALD L. IVES ${ }^{1}$
}

Conflicting territorial claims, plus repeated changes of sovereignty between 1540 and 1819 in what is now the western part of the United States, coupled with inaccurate maps and consequent nebulous geographical knowledge, resulted in . . . a territorial mixup the actual data concerning which are more complex than has heretofore been indicated. Much of the trouble leading up to the various boundary disputes seems occasioned by indefinite territorial claims, in large part due to vague geographic knowledge.

Following the initial discoveries by Columbus (1942), Spain's right to colonize the new world was strengthened by the Papal Bull of May 4, 1493, in which Pope Alexander VI set the western limit of Portuguese influence as a meridian 100 leagues west of the Cape Verde islands, and gave to Spain all new discoveries west of this line of demarcation. The next year, by the Treaty of Tordesillas, the line of demarcation was moved 370 leagues farther west, and the change was sanctified by a Bull of Pope Julius II in 1506.

Working northward and westward from the Caribbean, and northward from the mainland of Mexico, Spanish explorers soon penetrated parts of the North American mainland. The journeys of parties under Cabeza' de Vaca $^{2}$ (1529-1536), Fray Marcos de $\mathrm{Niza}^{3}$ (1539), Coronado $^{4}$ (1540-1542), and Juan de Onate ${ }^{5}$ (1601-1605), produced important data concerning the topography of Texas, New Mexico, Arizona, and adjacent parts of the Great Plains. Some of the conflicting claims of later

1Professor Ives is now with the Geography Department of Indiana University, and this excerpt is from an article by him appearing in full in the Colorado Magazine, (March, 1947, Vol. XXIV, No. 2).

${ }^{2}$ A F. Bandolier and F. Bandolier, The Journey of Cabeza de Vaca (Trail Makers Series, 1905). H. E. Bolton, The Spanish Borderlands. (New Haven, 1921), $2-45$.

${ }^{3}$ G. P. Winship, The Journey of Coronado (Trail Makers Series, 1904).

4 Ibid.

5G. P. Hammond, Don Juan de Onate and the Founding of New Mexica (Santa Fe, 1927). R. E. Twitchell, Leading Facts of New Mexico History (Cedar Rapids, 1911), 301-331. 
years date from these early explorations. In the peripheral areas were reputed to be the mythical kingdoms of Anian, Quivira, and Cibola, inhabited by strange and biologically-improbable beings.

Later explorations by Kino ${ }^{6}$ (1690-1710), Sadelmayr ${ }^{7}$ (1745) Dominguez and Escalante ${ }^{8}$ (1776), and Juan Bautista de Anza ${ }^{9}$ (1774-1776), and many others cleared up a large part of the mythical geography of earlier times, and strengthened the claims of Spain to lands west of the Rio Grande valley, but still left undefined the eastern and northern limits of the Spanish territories.

Overlapping the Spanish claims to what is now Colorado were the French Louisiana claims (1682-1762), and the somewhat nebulous coast-to-coast claims of the Council of New England, to lands north of the 40th parallel, from 1620 to 1635 ; and those of Virginia, to lands south of the 40 th parallel, from 1609 to $1763 .{ }^{10}$

Starting with the voyages of Breton fisherman to the Newfoundland fishing banks in about 1500, France rapidly gained territory, by right of exploration, in the New World. By way of the St. Lawrence Valley, missionaries, explorers, and fur-trappers penetrated the interior of the continent, establishing missions and trading posts as they went. In 1673, Marquette and Joliet reached the mouth of the Arkansas River, ${ }^{11}$ and decided that the Mississippi flowed into the Gulf of Mexico, a conclusion contradicting Marquette's former belief that the river emptied into the Vermillion Sea (Gulf of California).

French explorations continued, and in April, 1682, a party led by LaSalle reached the mouth of the Mississippi

'E. F. Kino (ed. by H. E. Bolton), Kino's Hisorical Memoir of Pimerial Alta (Cleveland, 1919).

'Jacob Sedelmayr (ed. by R. L. Ives), Sedelmayr's Relacion of 1746 (Bull. 123, Bur. Amer. Ethnology, 1939).

BS. V. Escalante and F. A. Dominque, Diaria... para descubrir el camino desde. . Sante Fe del Nuevo Mexico al de Monterey (Docs. para la hist. de
Mexico ser. II, Vol. i), 375-558.

'H. E. Bolton, Anza's California Expeditions (Berkeley, 1930).

10L. R. Hafen, Colorado, the Story of a Western Commonwealth (Denver, 1933), map opp. p. 95.

${ }^{11}$ Justin Winsor, Cartier to Frontenac (Boston, 1904) 199-202, 234-245, 247-250. 
and LaSalle claimed, for the king of France, an area probably intended to include the entire Mississippi drainage. Later establishment, by LaSalle, in 1685, of Fort St. Louis, on the Garcitas river in Texas, gave France a partial claim to some western lands not drained by the Mississippi. The exact boundaries of the Louisiana claims continued in dispute for more than a century, ${ }^{12}$ much of the uncertainity resulting from the claims supported by this Texan settlement.

By the year 1700, Spain and France had a number of conflicting territorial claims in North America. Of these, only the uncertainity of the boundary between the western edge of the Louisiana territory and the eastern limit of the lands of New Mexico is pertinent to this discussion. Although these conflicts were known to exist, and caused some alarm ${ }^{13}$ among the explorers, no real effort was made to resolve them.

By the secret treaty of November 3, 1762, commonly known as the "Family Compact," France ceded to Spain "all country known under the name of Louisiana. ..." but nowhere in the treaty is there any definition of this country. This cession eliminated, for the time, any problem of territorial boundaries in the Rocky Mountain region, for there was no longer any French-Spanish boundary there. The northern limit of the enlarged Spanish territory remained undefined.

France Regained Area

Thirty-eight years later, by the Treaty of San Ildefonso, in October, 1800, Spain retroceded the Louisiana territory to France, "with the same extent that it now has in the hands of Spain, and that it had when France possessed it." The treaty also stipulated that if this territory were ever again ceded, it must become the property of Spain. This transfer recreated the indefinite boundary between French and Spanish possessions in the Rocky Mountain region. 
During this thirty-eight year period, England acquired all lands east of the Mississippi, with the exception of Florida, by treaty, and then, as a result of the American Revolution, lost these same lands to the United States. Thus, after 1800, only Florida and those parts of LaSalle's original claim that lay west of the Mississippi were subject to change of soverignty. ${ }^{14}$

In accord with the treaty of April 30, 1803, and in return for a payment of $\$ 15,000,000$, France ceded to the United States "the said territory (Louisiana), with all its rights and appurtenances, as fully and in the same manner as they have been acquired by the French Republic." 15

This treaty not only left undefined the territories purchased by the United States, but was in conflict with the terms of the previous treaty by which France reacquired Louisiana. Although a Spanish protest was made, the United States took possession of the new lands, initiating a series of boundary disputes which were not settled for some years. The strong feeling aroused by the conflicting claims to parts of Texas was at least in part responsible for the Mexican War in 1846.

Immediately after the formal acquisition of Louisiana, the uncertainity of its boundaries, particularly on the west, became apparent. Some authorities believed that the Rio Grande was the western boundary; others that the Puerco or Salado formed the western limit south of the Rocky Mountains. The actual boundaries of Louisiana were never defined in any formal cession or treaty, in large part because nobody was sure what the territory contained, or how far it extended.

The only reasonably good definition of Louisiana is found in the grant by Louis XIV to sieur Antoine de Crozat (1712) in which trading rights were given.

\footnotetext{
14 A detailed description of these multiple changes in sovereignty is given by B. Hermann, The Louisiana Purchase (Govt. Printing Off., 1898). This work contains excellent maps.

${ }^{15}$ William MacDonald, Select Documents of United States History (New York, 1920), 162 .
} 
... in all the lands, possessed by us, and bounded by New Mexico, and by the lands of the English Carolina, ... the river of St. Lewis, heretofore called Mississippi, from the edge of the sea, as far as the Illinois, together with the river of St. Philip, heretofore called the Missourys. .. with all the countries, territories, lakes within land, and the rivers which fall directly or indirectly into that part of the river St. Lewis.

1. Our pleasure is that all the aforesaid lands, streams, rivers and islands, be and remain comprised under the name of the government of Louisiana. . ."16

According to a reasonably strict interpretation of this description, the United States certainly acquired a definite and incontestable title to the Mississippi water-shed. The boundary of this, in Colorado, was the Continental Divide between the Wyoming line and the vicinity of Salida; then the Arkansas-Rio Grande divide from the crest of the Collegiate Range above Salida, across Poncha Pass, to the crest of the Sangre de Cristo Range; and thence down the crest of this range to the New Mexico line. South of this, the boundary of the Mississippi drainage is the height of land running from west of Raton, New Mexico, southeastward.

If, on the strength of a number of indefinite claims based in large part on LaSalle's Fort St. Louis settlement, the boundary of Louisiana, as acquired by the United States, is set as the Rio Grande, then, south of Salida, the boundary follows the Divide to the head of the Rio Grande, in longitude $107^{\circ} 30^{\prime}$ approximately, and then down the Rio Grande to the Gulf. The status of this territory remained in doubt from 1803 until settled by the treaty of 1819 .

\section{SOUght Clarification of Claims}

After a period of growing tension and ill-feeling between the occupants of the borderlands, negotiations were entered into by Spain and the United States to re-

\footnotetext{
${ }^{16}$ Hermann, op. cit., 14-15. It will be noted that the section mentioning "lakes within lands" might reasonably include the "blind drainages" over which the soveignty of the United States has recently been questioned.
} 
solve the boundary problem. These resulted in the Treaty of 1819, also known as the Florida Treaty. This, dated February 22, 1819, sets the western boundary between the United States and Spain, in part, as

... following the course of the southern bank of the Arkansas, to its source, in latitude 42 north; and thence, by that parallel of latitude, to the South Sea. ... if the source of the Arkansas River shall be found to fall north or south of latitude 42 , then the line shall run from the said source due south or north, as the case may be, till it meets said parallel of latitude 42 .

The United States hereby cede to His Catholic Majesty and renounce forever, all their rights, claims, and pretensions, to the territories lying west and south of the above-described line; and, in like manner, His Catholic Majesty cedes to the said United States all his rights, claims and pretensions to any territories east and north of the said line. . . ${ }^{17}$

It is by this treaty that title to this so-called Colorado Enclave, reputed in newspaper stories and popular legends to be a territorial no-man's-land, came to the United States.

By all its clauses the treaty of 1819 clarified the claims of the various nations in North America. Important at a later date for our claims to the Oregon country was the definition of the northern limit of the Spanish claims at latitude 42 north and cession of Spain's Oregon claims to us.

17MacDonald, op. cit., 214-215.

Renewing its grant to the Newberry Library for the Newberry Fellowships in Midwestern Studies the Rockefeller Foundation has increased its former amount of $\$ 25,000$ to $\$ 50,000$ The Fellowships were awarded for the writing of sound and readable books about the Middle West. Applications are now being received by Stanley Pargellis, librarian of The Newberry, Chicago 10, Illinois. 
Copyright of Annals of Iowa is the property of State of Iowa, by \& through the State Historical Society of Iowa and its content may not be copied or emailed to multiple sites or posted to a listserv without the copyright holder's express written permission. However, users may print, download, or email articles for individual use. 